\title{
EVALUASI PENGENDALIAN AKUNTANSI ASET TETAP BERDASARKAN PERATURAN PEMERINTAH NOMOR 71 TAHUN 2010 TENTANG ASET TETAP PADA DINAS TENAGA KERJA DAN TRANSMIGRASI PROVINSI SULAWESI UTARA
}

\author{
Devid Manorek \\ Jenny Morasa \\ Harijanto Sabijono \\ Fakultas Ekonomi dan Bisnis Jurusan Akuntansi
Universitas Sam Ratulangi
Email: devidmanorek24@yahoo.com
}

ABSTRACT

Control of the Provincial Government Accounting is a systematic series of procedures organizers, equipment and other elements to realize the functions of accounting since the analysis of the transaction up to the financial reporting environment of the provincial government organizations. Fixed assets are tangible assets with a useful life of more than twelve (12) months for use in government activity or used by the general public. The purpose of this study was to evaluate control fixed asset accounting at the Department of Manpower and Transmigration of North Sulawesi Province. The results of this study indicate that accounting control of fixed assets at the Department of Manpower and Transmigration of North Sulawesi province in accordance with Government Regulation No. 71 Year 2010

Keywords : Control, fixed Assets, evaluation.

\section{Latar Belakang}

\section{Pendahuluan}

Aktivitas pengendalian intern merupakan kebijakan dan prosedur yang melindungi harta organisasi dari kemungkinan penyalahgunaan, memastikan bahwa informasi telah disajikan secara akurat dan memastikan bahwa peraturan telah dipatuhi sebagaimana mestinya. Pengendalian intern meliputi struktur organisasi dan segala cara serta tindakan dalam suatu perusahaan yang saling terkoordinasi dengan tujuan mengamankan harta kekayaan perusahaan, menguji ketelitian dan kebenaran data akuntansi, meningkatkan efisiensi operasi serta mendorong ketaatan terhadap kebijakan-kebijakan yang telah digariskan oleh pimpinan perusahaan. Sistem Pengendalian Intern dalam akuntansi memiliki peranan penting karena sistem pengendalian intern merupakan prosedur atau sistem yang dirancang untuk mengontrol, mengawasi, mengarahkan organisasi agar dapat mencapai suatu tujuan (La Midjan dan Susanto 2011:56).

Pengendalian akuntansi khususnya sektor publik menjadi suatu hal sangat penting untuk menjadikan organisasi sektor publik lebih profesional dalam mengelola keuangan negara.

Akuntansi aset tetap telah diatur dalam Pernyataan Standar Akuntansi Pemerintahan (PSAP) Nomor 7 (PSAP 07), dari Lampiran I PP 71 Tahun 2010. PSAP 07 tersebut memberikan pedoman bagi pemerintah dalam melakukan pengakuan, pengklasifikasian, pengukuran, dan pengungkapan aset tetap berdasarkan peristiwa yang terjadi, seperti perolehan aset tetap pertama kali, pemeliharaan aset tetap, pertukaran aset tetap, perolehan aset dari hibah/donasi, dan penyusutan.

Berdasarkan latar belakang di atas, penulis merasa tertarik untuk membuat karya ilmiah dengan judul : "Evaluasi Pengendalian Akuntansi Aset Tetap Berdasarkan Peraturan Pemerintah Nomor 71 Tahun 2010 Pada Dinas Tenaga Kerja dan Transmigrasi Provinsi Sulawesi Utara.” 


\section{Tujuan Penelitian}

Adapun tujuan yang ingin dicapai dalam penelitian ini adalah:

1. Untuk mengetahui penerapan PP Nomor 71 Tahun 2010 tentang aset tetap pada Dinas Tenaga Kerja dan Transmigrasi Provinsi Sulawesi Utara apakah telah efektif.

2. Untuk mengetahui pengendalian akuntansi aset tetap berdasarkan PP Nomor 71 Tahun 2010 pada Dinas Tenaga Kerja dan Transmigrasi Provinsi Sulawesi Utara apakah telah efektif.

\section{Konsep Akuntansi}

\section{TINJAUAN PUSTAKA}

\section{Definisi Akuntansi}

Menurut Weygandt, Kieso dan Kimmel (2011:4), definisi akuntansi, yaitu: "akuntansi adalah sebuah sistem informasi dimana mengindentifikasi, mencatat, dan melaporkan kinerja perusahaan kepada pihak terkait."

Wild, Shaw dan Chiappetta (2014:3) mendefinikan akuntansi adalah sistem informasi dan pengukuran yang mengidentifikasi, mencatat, dan mengkomunikasikan informasi yang relevan, dapat diandalkan, dan dapat dibandingkan tentang kegiatan bisnis organisasi.

Berdasarkan pengertian di atas, dapat disimpulkan konsep akuntansi adalah proses pengukuran yang melibatkan pencatatan, penggolongan dan pengiktisaran setiap transaksi bisnis yang terjadi dalam kegiatan bisnis yang dikomunikasikan melalui laporan keuangan selama periode tertentu bagi pengguna yang membutuhkannya.

\section{Standar Akuntansi Pemerintah Daerah}

Menurut Hariadi et al (2010:115), Standar akuntansi adalah acuan dalam penyajian laporan keuangan yang ditujukan kepada pihak-pihak di luar organisasi yang mempunyai otoritas tertinggi dalam kerangka akuntansi berlaku umum. Standar akuntansi berguna bagi penyusunan laporan keuangan dalam menentukan informasi yang harus disajikan kepada pihak-pihak yang di luar organisasi.

Akuntansi pemerintahan sendiri memiliki standar tersendiri yaitu Standar Akuntansi Pemerintahan. Menurut Permendagri No. 64 tahun 2013 pasal 1 ayat 3 menyatakan Standar Akuntansi Pemerintahan yang selanjutnya disingkat SAP adalah prinsip-prinsip akuntansi yang diterapkan dalam menyusun dan menyajikan laporan keuangan pemerintah.

Tanjung (2012:20) menyatakan yang termasuk dalam Peraturan Pemerintah No. 71 Tahun 2010 tentang Standar Akuntansi Pemerintahan adalah sebagai berikut :

PSAP 01 Penyajian Laporan Keuangan

PSAP 02 Laporan Realisasi Anggaran

PSAP 03 Laporan Aliran Kas

PSAP 04 Catatan atas Laporan Keuangan

PSAP 05 Akuntansi Persediaan

PSAP 06 Akuntansi Investasi

PSAP 07 Akuntansi Aset Tetap

PSAP 08 Akuntansi Konstruksi dalam Pengerjaan

PSAP 09 Akuntansi Kewajiban

PSAP 10 Koreksi Kesalahan

PSAP 11 Laporan Keuangan Konsolidasian

PSAP 12 Laporan Operasional 


\section{Pengendalian Akuntansi Sektor Publik}

Dalam Mahmudi (2010:20) dijelaskan bahwa sistem akuntansi berkaitan erat dengan sistem pengendalian internal organisasi. Pengendalian akuntansi mempunyai hubungan yang erat dengan pemeriksaan operasional.

Unsur-unsur struktur pengendalian akuntansi mencakup lima unsur pokok yang dirancang untuk dilaksanakan supaya memberikan kepastian yang jelas bahwa tujuan pengendalian akan tercapai. Unsurunsur struktur pengendalian intern berdasarkan standar profesional akuntan publik 2002 (PSA No. 69 Par 07) yaitu:

1. Lingkungan Pengendalian

2. Penafsiran Resiko

3. Aktivitas Pengendalian

4. Informasi dan Komunikasi

5. Pemantauan

\section{Pengertian Aset Tetap}

Pengertian aset tetap menurut Kieso et al (2010:490) aset tetap adalah "property, plant, and equipment invlude land, building structure (office, factories, warehouse), and equipment (machinery, furniture, tools)".

\section{Jenis Aset Tetap}

Aset tetap berwujud yang dimiliki oleh suatu perusahaan bisa berupa: tanah, bangunan, mesin dan alat-alat pabrik, meubel dan alat-alat kantor, kendaraan dan alat-alat kantor dan sebagainya.

Ditinjau dari umurnya aset tetap dibedakan menjadi tiga golongan, yaitu:

1. Aset tetap yang umur atau masa kegunaannya tidak terbatas. Termasuk dalam kelompok aset ini ialah; tanah yang dipakai sebagai tempat kedudukan bangunan pabrik dan bangunan kantor, tanah untuk pertanian dan lain-lain yang semacamnya.

2. Aset tetap yang umur atau masa kegunaannya terbatas, dan dapat diganti dengan aktiva sejenis apabila masa kegunaanya telah berakhir.

3. Aset tetap yang umur atau masa kegunaannya terbatas, dan tidak dapat diganti dengan aset sejenis apabila masa kegunaanya telah habis.

Ditinjau dari mobilitasnya, aset tetap dibedakan menjadi dua golongan, yaitu:

1. Aset tetap berwujud bergerak, yaitu aktiva tetap berwujud yang dapat dengan mudah berpindah atau dipindahkan. Misalnya kendaraan, perlengkapan dan sebagainya.

2. Aset tetap berwujud tidak bergerak, misalnya tanah, gedung dan sebagainya.

Ditinjau dari undang-undang perpajakan, aset tetap dibedakan menjadi empat golongan, yaitu:

1. Golongan I, yaitu aset tetap selain bangunan yang mempunyai umur ekonomis sampai 4 tahun, misalnya: peralatan, mebel, kendaraan, dan truk ringan.

2. Golongan II, yaitu aset tetap selain bangunan yang mempunyai umur ekonomis diatas 4 tahun, misalnya: mebel dan peralatan yang terbuat dari logam, truk berat, mobil tangki, dll.

3. Golongan III, yaitu aset tetap selain bangunan yang mempunyai umur ekonomis antara 8 sampai 20 tahun, misalnya: mesin-mesin yang menghasilkan peralatan, mesin produksi, dll.

4. Golongan IV, yaitu aset tetap berwujud yang berupa tanah dan bangunan.

\section{Pengertian Aset Tetap Sektor Publik}

Menurut Lampiran II.08 PPRI No. 71 Tahun 2010 tentang Standar Akuntansi Pemerintahan Pernyataan No.07 Aset adalah sumber daya ekonomi yang dikuasai atau dimiliki oleh pemerintah sebagai akibat dari peristiwa masa lalu dan dari mana manfaat ekonomi atau sosial dimasa depan diharapkan dapat diperoleh, baik oleh pemerintah maupun masyarakat, serta dapat diukur dalam satuan uang. 
Aset Tetap adalah aset berwujud yang mempunyai masa manfaat lebih dari dua belas (12) bulan untuk digunakan dalam kegiatan pemerintahan atau dimanfaatkan oleh masyarakat umum.

\section{Tahap-tahap Pengelolaan Aset Tetap Sektor Publik}

Yusuf (2011) dalam bukunya 8 Langkah Pengelolaan Aset Daerah menyatakan siklus pengelolaan aset adalah tahapan-tahapan yang harus dilalui dalam manajemen aset. Dalam Permendagri No. 17 tahun 2007 disebutkan bahwa yang dimaksud dengan Pengelolaan barang daerah adalah suatu rangkaian kegiatan dan tindakan terhadap daerah yang meliputi:

1. Perencanaan kebutuhan dan penganggaran;

2. Pengadaan;

3. Penerimaan, penyimpanan dan penyaluran;

4. Penggunaan;

5. Penatausahaan;

6. Pemanfaatan;

7. Pengamanan dan pemeliharaan;

8. Penilaian;

9. Penghapusan;

10. Pemindahtanganan;

11. Pembinaan, Pengawasan, dan Pengendalian;

12. Pembiayaan;

13. Tuntutan ganti rugi;

\section{Klasifikasi Aset Tetap Sektor Publik}

Menurut Lampiran II.08 PPRI No. 71 Tahun 2010 tentang Standar Akuntansi Pemerintahan Pernyataan No.07 Aset tetap diklasifikasikan berdasarkan kesamaan dalam sifat atau fungsinya dalam aktivitas operasi entitas. Berikut adalah klasifikasi aset tetap yang digunakan:

1. Tanah

2. Peralatan dan mesin

3. Gedung dan bangunan

4. Jalan, irigasi dan jaringan

5. Kontruksi dalam pengerjaan

6. Aset tetap lainnya

\section{Pengakuan Aset Tetap Sektor Publik}

Pengakuan aset tetap adalah aset tetap diakui pada saat manfaat ekonomi masa depan dapat diperoleh dan nilainya dapat diukur dengan handal. Untuk dapat diakui sebagai aset tetap, menurut Lampiran II.08 PPRI N.71 Tahun 2010 suatu aset harus berwujud dan memenuhi kriteria, yaitu:

a. Berwujud.

b. Mempunyai masa manfaat lebih dari dua belas (12) bulan. Masa manfaat adalah periode suatu aset diharapkan digunakan untuk aktivitas pemerintahan atau pelayanan publik dan jumlah produksi atau unit serupa yang diharapkan diperoleh dari aset untuk aktivitas pemerintahan atau pelayanan publik.

c. Biaya perolehan aset dapat diukur secara handal.

d. Tidak dimaksudkan untuk dijual dalam operasi normal entitas.

e. Diperoleh atau dibangun dengan maksud untuk digunakan.

f. Merupakan objek pemeliharaan atau memerlukan biaya/ongkos untuk dipelihara.

g. Nilai rupiah pembelian barang material atau pengeluaran untuk pembelian barang tersebut mempunyai batas minimal kapitalisasi asset tetap yang telah ditetapkan. 
Tujuan utama dari perolehan aset tetap adalah untuk digunakan oleh pemerintah dalam mendukung kegiatan operasionalnya dan bukan dimaksudkan untuk dijual. Pengakuan aset tetap akan handal bila aset tetap telah diterima atau diserahkan hak kepemilikannya atau pada saat penguasaannya berpindah.

\section{Pengukuran Aset Tetap Sektor Publik}

Menurut Lampiran II.08 PPRI No. 71 Tahun 2010 tentang Standar Akuntansi Pemerintahan Pernyataan No.07 aset tetap dinilai dengan biaya perolehan. Apabila penilaian aset tetap dengan menggunakan biaya perolehan tidak memungkinkan maka nilai aset tetap didasarkan pada nilai wajar pada saat perolehan.

1. Penilaian awal aset tetap

2. Komponen Biaya

3. Pengecualian Komponen Biaya Perolehan aset tetap

4. Kontruksi dalam pengerjaan

5. Perolehan secara gabungan

6. Pertukaran aset.

7. Aset Donasi

8. Pengeluaran Setelah Perolehan (Subsequent Expenditures)

9. Pengukuran berikut (Subsequen measurement) terhadap pengakuan awal

\section{Penilaian Kembali Aset Tetap Sektor Publik}

Penilaian kembali atau revaluasi aset tetap pada umumnya tidak diperkenankan karena Standar Akuntansi Pemerintahan menganut penilaian aset berdasarkan biaya perolehan atau harga pertukaran. Penyimpangan dari ketentuan ini mungkin dilakukan berdasarkan ketentuan pemerintah yang berlaku secara nasional.

\section{Penghentian dan Pengungkapan Aset Tetap Sektor Publik}

1. Penghentian

Suatu aset tetap dieliminasi dari neraca ketika dilepaskan atau bila aset secara permanen dihentikan penggunaannya dan tidak ada manfaat ekonomi masa yang akan datang. Aset tetap yang secara permanen dihentikan atau dilepas harus dieliminasi dari neraca dan diungkapkan dalam catatan atas laporan keungan. Aset tetap yang dihentikan dari dihentikan dari penggunaan aktif pemerintahan tidak memenuhi definisi aset tetap dan harus dipindahkan ke pos aset lainnya sesuai dengan nilai tercatatnya.

2. Pengungkapan berikut:

Laporan keuangan harus mengungkapkan untuk masing- masing jenis aset tetap sebagai

a. Dasar penilaian yang digunakan yang digunakan untuk menentukan nilai tercat (carrying amount)

b. Rekonsiliasi jumlah tercatat pada awal dan akhir periode

c. Informasi penyusutan

3. Pengungkapan

Laporan keuangan juga harus mengungkapkan:

a. Eksistensi dan batasan hak milik atas aset tetap

b. Kebijakan akuntansi untuk kapitalisasi yang berkaitan dengan aset tetap

c. Jumlah pengeluaran pada pos aset tetap dalam konstuksi

d. Jumlah komitmen untuk akuisisi aset tetap 


\section{Penelitian Terdahulu}

1. Akhyar Tipan (2015) dengan judul Analisis Perlakuan Akuntansi Aset Tetap Pada Dinas Pekerjaan Umum (PU) Provinsi Sulawesi Utara. Tujuan penelitian ini menganalisis bagaimana prosedur perlakuan akuntansi aset tetap pada Dinas Pekerjaan Umum Sulawesi Utara. Penelitian ini menggunakan metode peneltian deskriptif. Hasil Penelitian ini perlakuan akuntansi aset tetap pada Dinas Pekerjaan Umum telah sesuai dengan PSAP. No. 07.

2. Monika Sutri Kolinug (2015) dengan judul Analisis Pengelolaan Aset Tetap Pada Dinas Pendapatan Pengelolaan Keuangan dan Aset Daerah Kota Tomohon. Tujuan Penelitian ini mengetahui kesesuaian pengelolaan aset tetap pada Dinas Pendapatan Pengelolaan Keuangan dan Aset Daerah Kota Tomohon dengan Peraturan Menteri Dalam Negeri No. 17 Tahun 2007. Penelitian ini menggunakan metode penelitian deskriptif. Hasil penelitian ini pengelolaan Aset Tetap pada Dinas Pendapatan Pengelolaan Keuangan dan Aset Daerah Kota Tomohon telah sesuai dengan Peraturan Menteri Dalam Negeri No. 17 Tahun 2007

\section{METODE PENELITIAN}

\section{Hasil Penelitian}

Dinas Tenaga Kerja dan Transmigrasi Provinsi Sulawesi Utara merupakan salah satu Satuan Kerja Perangkat Daerah (SKPD) yang mempunyai tugas untuk membantu pemerintah dan masyarakat berdasarkan Peraturan Pemerintah No. 71 Tahun 2010. Pada Dinas Tenaga Kerja dan Transmigrasi Provinsi Sulawesi Utara, aset tetap memiliki pengertian yang sama dengan pengertian aset tetap yang termuat dalam Pernyataan Standar Akuntansi Pemerintahan (PSAP). Dalam Pernyataan Standar Akuntansi Pemerintah (PSAP) Nomor 7 (PSAP 07), dari Lampiran I PP 71 Tahun 2010 prosedur aset tetap terdiri dari pengakuan aset tetap, pengukuran aset tetap, pengklasifikasian aset tetap, dan pengungkapan aset tetap. Dalam wawancara pada Dinas Tenaga Kerja dan Transmigrasi Provinsi Sulawesi Utara Standar Operasional Prosedur menjelaskan rangkaian kegiatan untuk pengelolaan aset tetap dari rangkaian kegiatan yang dilaksanakan sesuai dengan Peraturan Pemerintah No. 71 tahun 2010 tetang Standar Akuntansi Pemerintahan. Tabel-tabel dibawah ini adalah perbandingan prosedur pengendalian aset tetap Dinas Tenaga Kerja dan Transmigrasi Provinsi Sulawesi Utara dengan Peraturan Pemerintah No. 71 Tahun 2010, pernyataan 07.

Tabel 4.2.1

Pengakuan Aset Tetap oleh Dinas Tenaga Kerja dan Transmigrasi Prov. Sulawesi Utara dengan PSAP No. 07.

\begin{tabular}{|c|c|c|}
\hline PSAP 07 & $\begin{array}{llll}\text { Dinas Tenaga Kerja } & \text { dan } & \text { Transmigrasi } \\
\text { Provinsi Sulawesi Utara } & & \end{array}$ & Keterangan \\
\hline $\begin{array}{l}\text { 1. Masa manfaat lebih } \\
\text { dari } 12 \text { (dua belas) } \\
\text { bulan. }\end{array}$ & $\begin{array}{l}\text { 1. Pada Dinas Tenaga Kerja dan } \\
\text { Transmigrasi Provinsi Sulawesi } \\
\text { Utara, apabila aset tetap tersebut } \\
\text { memiliki manfaat lebih dari } 12 \text { (dua } \\
\text { belas) bulan,maka aset tersbut } \\
\text { dikategorikan sebagai aset tetap. }\end{array}$ & Sesuai \\
\hline 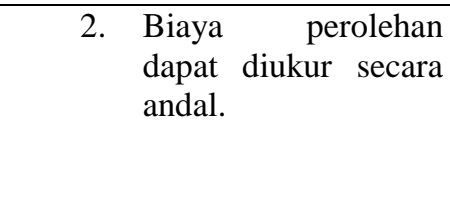 & $\begin{array}{l}\text { 2. Pada Dinas Tenaga Kerja dan } \\
\text { Transmigrasi Provinsi Sulawesi } \\
\text { Utara, aset tetap diakui } \\
\text { menggunakan biaya perolehan yang } \\
\text { dapat diukur secara andal. }\end{array}$ & Sesuai \\
\hline $\begin{array}{l}\text { 3. } \\
\text { Tidak dimaksudkan } \\
\text { untuk dijual dalam }\end{array}$ & $\begin{array}{lllr}\text { 3. } & \text { Pada Dinas } & \text { Tenaga Kerja dan } \\
& \text { Transmigrasi } & \text { Provinsi } & \text { Sulawesi }\end{array}$ & Sesuai \\
\hline
\end{tabular}




\begin{tabular}{|c|c|c|c|}
\hline & normal & $\begin{array}{llr}\text { Utara, pengadaan aset } & \text { tetap } \\
\text { dimaksudkan bukan untuk } & \text { dijual } \\
\text { melainkan } & \text { digunakan } & \text { untuk } \\
\text { menunjang } & \text { kegiatan } & \text { opersional } \\
\text { entitas. } & & \end{array}$ & \\
\hline 4. & $\begin{array}{l}\text { Diperoleh } \\
\text { dibangun } \\
\text { maksud } \\
\text { digunakan. }\end{array}$ & $\begin{array}{l}\text { 4. Pada Dinas Tenaga Kerja dan } \\
\text { Transmigrasi Provinsi Sulawesi } \\
\text { Utara, aset tetap diperoleh atau } \\
\text { dibangun untuk digunakan dalm } \\
\text { aktifitas entitas. Contohnya } \\
\text { pengadaan kursi yang akan } \\
\text { digunakan oleh para pegawai yang } \\
\text { ada di Dinas Tenaga Kerja dan } \\
\text { Transmigrasi Provinsi Sulawesi } \\
\text { Utara. }\end{array}$ & Sesuai \\
\hline & $\begin{array}{l}\text { Pengakuan aset tetap } \\
\text { akan sangat andal } \\
\text { apabila aset tetap } \\
\text { telah diterima atau } \\
\text { diserahkan hak } \\
\text { kepemilikannya pada } \\
\text { saat penguasaannya } \\
\text { berpindah. }\end{array}$ & $\begin{array}{l}\text { 5. Pada Dinas Tenaga Kerja dan } \\
\text { Transmigrasi Provinsi Sulawesi } \\
\text { Utara, aset tetap akan diakui pada } \\
\text { saat penandatanganan berita acara } \\
\text { penerimaan aset tetap. }\end{array}$ & Sesuai \\
\hline
\end{tabular}

(sumber: data olahan, 2016)

Dari tabel 4.2.1 di atas terlihat bahwa pengendalian akuntansi aset tetap khususnya untuk aspek pengakuan aset tetap pada Dinas Tenaga Kerja dan Transmigrasi Provinsi Sulawesi Utara telah sesuai dengan peraturan pemerintah yang berlaku yaitu Peraturan Pemerintah No. 71 Tahun 2010 pernyataan No. 07 tentang akuntansi aset tetap, mulai dari masa manfaat aset yang harus lebih dari 12 bulan sampai pada diakuinya aset sebagai aset tetap. Menurut penulis Dinas Tenaga Kerja dan Transmigrasi Provinsi Sulawesi Utara telah mengikuti peraturan yang berlaku.

Tabel 4.2.2

Pengukuran Aset Tetap oleh Dinas Tenaga Kerja dan Transmigrasi Prov. Sulawesi Utara dengan PSAP No. 07

\begin{tabular}{|c|c|c|}
\hline PSAP 07 & $\begin{array}{llll}\text { Dinas Tenaga Kerja dan } & \text { Transmigrasi } \\
\text { Provinsi Sulawesi Utara } & & \\
\end{array}$ & Keterangan \\
\hline $\begin{array}{lr}\text { 1. } \begin{array}{l}\text { Aset tetap } \\
\text { dengan }\end{array} & \begin{array}{r}\text { dinilai } \\
\text { biaya }\end{array} \\
\text { perolehan. Apabila } \\
\text { penilaian aset tetap } \\
\text { dengan } & \text { biaya } \\
\text { perolehan tidak } & \text { memungkinkan maka } \\
\text { nilai aset tetap } \\
\text { didasarkan pada nilai } \\
\text { wajar pada saat } \\
\text { perolehan }\end{array}$ & $\begin{array}{l}\text { 1. Pada Dinas Tenaga Kerja dan } \\
\text { Transmigrasi Provinsi Sulawesi } \\
\text { Utara, penilaian atas suatu aset tetap } \\
\text { menggunakan biaya perolehan yaitu } \\
\text { biaya yang dinilai berdasarkan } \\
\text { seluruh biaya yang dikeluarkan } \\
\text { hingga aset tetap tersebut siap untuk } \\
\text { digunakan. }\end{array}$ & Sesuai \\
\hline $\begin{array}{l}\text { 2. Biaya perolehan suatu } \\
\text { aset tetap terdiri dari } \\
\text { harga } \quad \text { belinya } \\
\text { termasuk bea impor }\end{array}$ & $\begin{array}{l}\text { 2. Pada Dinas Tenaga Kerja dan } \\
\text { Transmigrasi } \text { Provinsi Sulawesi } \\
\text { Utara, biaya perolehan suatu aset } \\
\text { tetap diukur dari harga beli aset }\end{array}$ & Sesuai \\
\hline
\end{tabular}




\begin{tabular}{|l|l|l|}
\hline $\begin{array}{l}\text { dan setiap biaya yang } \\
\text { dapat diatribusikan } \\
\text { secara langsung. }\end{array}$ & $\begin{array}{l}\text { tetap, biaya angkut dan biaya } \\
\text { instalasi yang dikeluarkan untuk aset } \\
\text { tetap tersebut }\end{array}$ & \\
\hline
\end{tabular}

(sumber: data olahan, 2016)

Berdasarkan tabel 4.2.2 diatas bahwa pengendalian akuntansi aset tetap khususnya untuk aspek pengukuran aset tetap pada Dinas Tenaga Kerja dan Transmigrasi Provinsi Sulawesi Utara telah sesuai dengan peraturan pemerintah yang berlaku, yaitu Peraturan Pemerintah No. 71 tahun 2010 pernyataan No. 07 tentang akuntansi aset tetap. Menurut penulis pengendalian akuntansi khususnya pengukuran aset tetap Dinas Tenaga Kerja dan Transmigrasi Provinsi Sulawesi Utara dinilai dengan biaya perolehan.

Tabel 4.2.3

Pengaklasifikasian Aset Tetap oleh Dinas Tenaga Kerja dan Transmigrasi Provinsi Sulawesi Utara dengan PSAP No. 07

\begin{tabular}{|c|c|c|}
\hline PSAP 07 & $\begin{array}{llll}\text { Dinas Tenaga Kerja dan } & \text { Transmigrasi } \\
\text { Provinsi Sulawesi Utara } & & \\
\end{array}$ & Keterangan \\
\hline $\begin{array}{l}\text { 1. Aset tetap dalam } \\
\text { pemerintahan } \\
\text { diklasifikasikan ke } \\
\text { dalam beberapa } \\
\text { kelompok, yaitu: } \\
\text { tanah; peralatan dan } \\
\text { mesin; gedung atau } \\
\text { bangunan; jalan, } \\
\text { irigasi dan jaringan; } \\
\text { serta aset tetap } \\
\text { lainnya. }\end{array}$ & $\begin{array}{l}\text { 1. Pada Dinas Tenaga Kerja dan } \\
\text { Transmigrasi Provinsi Sulawesi } \\
\text { Utara, aset tetap telah } \\
\text { dikalsifikasikan ke dalam beberapa } \\
\text { kelompok, yaitu: tanah; peralatan } \\
\text { dan mesin; gedung atau bangunan; } \\
\text { jalan, irigasi dan jaringan; serta aset } \\
\text { tetap lainnya. }\end{array}$ & Sesuai \\
\hline $\begin{array}{l}\text { 2. Aset tetap digunakan } \\
\text { juga untuk } \\
\text { kepentingan publik }\end{array}$ & $\begin{array}{l}\text { 2. Pada Dinas Tenaga Kerja dan } \\
\text { Transmigrasi Provinsi Sulawesi } \\
\text { Utara, aset tetap yang telah } \\
\text { diklasifikasi tidak hanya digunakan } \\
\text { dalam kagiatan pemerintahan, tetapi } \\
\text { juga digunakan untuk kepentingan } \\
\text { publik. }\end{array}$ & Sesuai \\
\hline $\begin{array}{lr}\text { 3. } & \text { Tanah yang } \\
\text { dikelompokkan } & \\
\text { sebagai aset tetap } \\
\text { adalah tanah yang } \\
\text { diperoleh dengan } \\
\text { maksud rantuk } \\
\text { dipakai dalam } \\
\text { kegiatan operasional } \\
\text { pemerintah r dan } \\
\text { dalam kondisi siap } \\
\text { pakai } \\
\end{array}$ & $\begin{array}{l}\text { 3. Pada Dinas Tenaga Kerja dan } \\
\text { Transmigrasi Provinsi Sulawesi } \\
\text { Utara, tanah diklasifikasikan } \\
\text { sebagai aset tetap untuk tempat } \\
\text { pembangunan gedung/kantor dan } \\
\text { siap pakai. }\end{array}$ & Sesuai \\
\hline 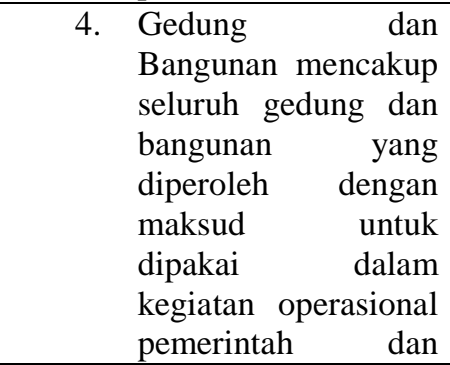 & $\begin{array}{l}\text { 4. Pada Dinas Tenaga Kerja dan } \\
\text { Transmigrasi Provinsi Sulawesi } \\
\text { Utara, gedung dan bangunan } \\
\text { diklasifikasikan dalam aset tetap } \\
\text { untuk kegiatan operasional para } \\
\text { pegawai dan siap pakai. }\end{array}$ & Sesuai \\
\hline
\end{tabular}




\begin{tabular}{|c|c|c|c|}
\hline & $\begin{array}{l}\text { dalam kondisi siap } \\
\text { pakai. }\end{array}$ & & \\
\hline & $\begin{array}{l}\text { Peralatan dan mesin } \\
\text { mencakup mesin- } \\
\text { mesin dan kendaraan } \\
\text { bermotor, alat } \\
\text { elektronik, inventaris } \\
\text { kantor, dan peralatan } \\
\text { lainnya yang nilainya } \\
\text { signifikan dan masa } \\
\text { manfaatnya lebih } \\
\text { dari 12 (dua belas) } \\
\text { bulan dan dalam } \\
\text { kondisi siap pakai. }\end{array}$ & $\begin{array}{l}\text { 5. Pada Dinas Tenaga Kerja dan } \\
\text { Transmigrasi Provinsi Sulawesi } \\
\text { Utara, peralatan dan mesin } \\
\text { diklasifikasikan dalam aset tetap, } \\
\text { yang memiliki manfaat lebih dari } 12 \\
\text { (dua belas) bulan, seperti kendaraan } \\
\text { dinas, mesin foto copy, dan lain } \\
\text { sebagainya serta untuk kegiatan } \\
\text { operasional pemerintah dan dalam } \\
\text { kondisi siap pakai. }\end{array}$ & Sesuai \\
\hline & $\begin{array}{l}\text { Jalan, irigasi dan } \\
\text { jaringan mencakup } \\
\text { jalan, yang dibangun } \\
\text { oleh pemerintah serta } \\
\text { dimiliki dan/atau } \\
\text { dikuasai r oleh } \\
\text { pemerintah dan } \\
\text { dalam kondisi siap } \\
\text { pakai. }\end{array}$ & $\begin{array}{l}\text { 6. Jalan, irigasi dan jaringa mencakup } \\
\text { jalan, diklasifikasikan dalam aset } \\
\text { tetap yang berupa bursa kerja oleh } \\
\text { Dinas Tenaga Kerja dan } \\
\text { Transmigrasi Provinsi Sulawesi } \\
\text { Utara, dan dalam kondisi yang siap } \\
\text { pakai. }\end{array}$ & Sesuai \\
\hline 7. & $\begin{array}{l}\text { Aset tetap lainnya } \\
\text { mencakup aset tetap } \\
\text { yang tidak dapat } \\
\text { dikelompokkan ke } \\
\text { dalam kelompok aset } \\
\text { tetap diatas, yang } \\
\text { diperoleh dan } \\
\text { dimanfaatkan untuk } \\
\text { kegiatan operasional } \\
\text { pemerintah dan } \\
\text { dalam kondisi siap } \\
\text { pakai. }\end{array}$ & $\begin{array}{l}\text { 7. Pada Dinas Tenaga Kerja dan } \\
\text { Transmigrasi Provinsi Sulawesi } \\
\text { Utara, aset tetap lainnya } \\
\text { diklasifikasikan dalam aset tetap } \\
\text { yang tidak dikelompokkan ke dalam } \\
\text { kelomok aset tetap diatas, yang } \\
\text { diperoleh untuk digunakan dalam } \\
\text { kegiatan operasional pemerintah } \\
\text { dan dalam kondisi siap pakai. }\end{array}$ & Sesuai \\
\hline
\end{tabular}

(sumber: data olahan, 2016)

Berdasarkan tabel 4.2.3 diatas terlihat bahwa Pengendalian akuntansi aset tetap khususnya untuk aspek pengklasifikasian aset tetap oleh Dinas Tenaga Kerja dan Transmigrasi Provinsi Sulawesi Utara telah sesuai dengan peraturan pemerintah yang berlaku, yaitu Peraturan Pemerintah No. 71 tahun 2010 pernyataan No. 07 tentang akuntansi aset tetap. Menurut penulis pengendalian akuntansi aset tetap khususnya untuk aspek pengklasifikasian aset tetap Dinas Tenaga Kerja dan Transmigrasi Provinsi Sulawesi Utara, diklasifikasikan berdasarkan kesamaan dalam satu sifat atau fungsinya dalam aktivitas entitas.

Tabel 4.2.4

Pengungkapan Aset Tetap oleh Dinas Tenaga Kerja dan Transmigrasi Provinsi Sulawesi Utara dengan PSAP No. 07

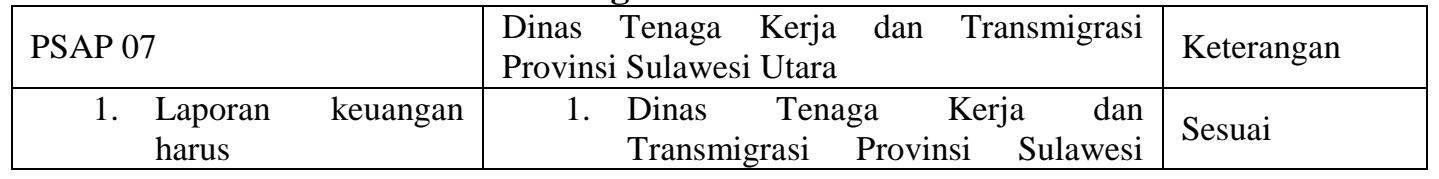




\begin{tabular}{|c|c|c|c|c|}
\hline & $\begin{array}{l}\text { mengungkapkan } \\
\text { dasar penilaian yang } \\
\text { digunakan untuk } \\
\text { menentukan nilai } \\
\text { tercatat }\end{array}$ & & $\begin{array}{l}\text { Utara mengungkapkan } \\
\text { penilaian yang digunakan untuk } \\
\text { menentukan nilai tercatat dalam } \\
\text { laporan keuangan, yaitu aset tetap } \\
\text { dinilai dengan biaya perolehan. }\end{array}$ & \\
\hline & $\begin{array}{lr}\text { Setiap jenis aset tetap } \\
\text { seperti tanah; } \\
\text { peralatan dan mesin; } \\
\text { gedung atau } \\
\text { bangunan; } \\
\text { irigasi dan jaringan; } \\
\text { serta aset tetap } \\
\text { lainnya } & \text { harus } \\
\text { dinyatakan dalam } \\
\text { neraca terpisah atau } \\
\text { terperinci a dalam } \\
\text { Catatan Atas Laporan } \\
\text { Keuangan. }\end{array}$ & & $\begin{array}{l}\text { Semua aset tetap yang dimiliki oleh } \\
\text { Dinas Tenaga Kerja dan } \\
\text { Transmigrasi Provinsi Sulawesi } \\
\text { Utara seperti tanah; peralatan dan } \\
\text { mesin; gedung atau bangunan; jalan, } \\
\text { irigasi dan jaringan; serta aset tetap } \\
\text { lainnya dinyatakan secara terpisah } \\
\text { dalam neraca dan terperinci dalam } \\
\text { Catatan Atas Laporan Keuangan } \\
\text { (CALK) entitas. }\end{array}$ & Sesuai \\
\hline & $\begin{array}{l}\text { Rekonsiliasi jumlah } \\
\text { tercatat pada awal } \\
\text { dan akhir periode } \\
\text { yang menunjukkan } \\
\text { penambahan, } \\
\text { pelepasan, dan } \\
\text { perunahan nilai jika } \\
\text { ada mutasi aset tetap } \\
\text { lainnya }\end{array}$ & & $\begin{array}{l}\text { Laporan Keuangan Dinas Tenaga } \\
\text { Kerja dan Transmigrasi Provinsi } \\
\text { Sulawesi Utara, mengungkapkan } \\
\text { rekonsiliasi jumlah tercatat yang } \\
\text { menunjukkan pelepasan dan mutasi } \\
\text { aset tetap lainnya selama periode } \\
\text { tahun berjalan. }\end{array}$ & Sesuai \\
\hline
\end{tabular}

(sumber: data olahan, 2016)

Pada tabel 4.2.4 di atas terlihat bahwa pengendalian akuntansi aset tetap khususnya untuk aspek pengungkapan aset tetap pada Dinas Tenaga Kerja dan Transmigrasi Provinsi Sulawesi Utara telah sesuai dengan peraturan pemerintah yang berlaku, yaitu Peraturan Pemerintah No. 71 tahun 2010 pernyataan No. 07 tentang akuntansi aset tetap. Menurut penulis Menurut pengendalian akuntansi aset tetap khususnya untuk aspek pengungkapan aset tetap Dinas Tenaga Kerja dan Transmigrasi Provinsi Sulawesi Utara mengungkapkan dasar penilaian yang digunakan untuk menilai suatu aset, selain itu setiap jenis aset yang dimiliki juga disajikan secara terpisah dalam neraca dan terperinci dalam Catatan Atas Laporan Keuangan. saham.

Salah satu perusahaan beroperasi adalah menghasilkan laba yang bermanfaat bagi para pemegang

\section{Pembahasan}

Dokumen sumber adalah semua berkas penting yang dihasilkan dari siklus pengelolaan aset tersebut maupun berkas penting yang mendasari suatu siklus/tahapan untuk dilakukan. Pengelolaan aset tetap pada dasarnya dilakukan untuk menghasilkan informasi yang andal. Dalam pengelolaan aset tetap perlu adanya pengendalian akuntansi aset tetap yang dapat menilai proses pengelolaan aset tetap mulai dari proses pengadaan sampai pada penggunaan aset tetap tersebut.

Dinas Tenaga Kerja dan Transmigrasi Provinsi Sulawesi Utara memiliki Standar Operasional Prosedur (SOP) untuk pengadaan aset tetap mulai dari proses pengadaan sampai pada penggunan aset tetap tersebut. Standar Operasional Prosedur (SOP) dari Dinas Tenaga Kerja dan Transmigrasi Provinsi Sulawesi Utara adalah :

1. Perencanaan untuk pengadaan barang sesuai dengan DPA SKPD.

2. Melaksanakan Survey spesifikasi barang berdasarkan harga. 
3. Melaksanakan pengadaan barang sesuai dengan dokumen pengadaan.

4. Melaksanakan verivikasi terhadap barang yang telah diadakan.

5. Pembuatan berita acara penerimaan.

6. Pencatatan barang yang telah diakui sebagai aset tetap pada Dinas Tenaga Kerja dan Transmigrasi Provinsi Sulawesi Utara.

7. Mengadakan penyaluran barang ke unit kerja yang membutuhkan sesuai perencanaan.

8. Melakukan pengawasan terhadap aset tetap.

9. Pembuatan laporan pertanggungjawaban sesuai dengan klasifikasi inventaris barang.

10. Pemeriksaan laporan pertanggungjawaban pengadaan aset tetap.

11. pemeliharaan aset tetap Dinas Tenaga Kerja dan Transmigrasi Provinsi Sulawesi Utara.

Hasil penelitian menunjukkan bahwa Standar Operasional Prosedur (SOP) pengadaan aset tetap dari Dinas Tenaga Kerja dan Transmigrasi Provinsi Sulawesi Utara merupakan prosedur pengendalian akuntansi aset tetap, yang memiliki keterkaitan dengan Peraturan Pemerintah No. 71 Tahun 2010, dimana Standar Operasional Prosedur tersebut di atas dapat digolongkan pada beberapa poin yang ada dalam Peraturan Pemerintah No. 71 Tahun 2010, seperti pengakuan aset tetap, pengukuran aset tetap, pengklasifikasian aset tetap dan pengungkapan aset tetap.

Sesuai dengan tabel-tabel perbandingan yang ada pada sub bab 4.3 yaitu hasil penelitian, penggolongan pengendalian akuntansi aset tetap berdasarkan Peraturan Pemerintah No. 71 Tahun 2010 pada Dinas Tenaga Kerja dan Transmigrasi Provinsi Sulawesi Utara adalah sebagai berikut :

1. Dalam PSAP No. 07 Pengakuan aset tetap berhubungan dengan Standar Operasional Prosedur Dinas Tenaga Kerja dan Transmigrasi Provinsi Sulawesi Utara yaitu pada poin 1 (satu) Pejabat Pelaksana Teknis Kegiatan (PPTK) merencanakan untuk pengadaan barang sesuai dengan DPA SKPD, poin 5 (lima) pembuatan berita acara penerimaan dan poin 6 (enam) pencatatan barang yang telah diakui sebagai aset tetap pada Dinas Tenaga Kerja dan Transmigrasi Provinsi Sulawesi Utara. Dalam hal ini barang yang telah dibeli akan diakui sebagai aset tetap pada saat barang sudah diterima dan ditandatangani KASUBAG Umum.

2. Dalam PSAP No. 07 Pengukuran aset tetap berhubungan dengan Standar Operasional Prosedur Dinas Tenaga Kerja dan Transmigrasi Provinsi Sulawesi Utara yaitu pada poin 2 (dua) melaksanakan survey spesifikasi barang berdasarkan harga. Dalam hal ini aset tetap diukur berdasarkan harga perolehan barang sesuai dengan spesifikasi harga.

3. Dalam PSAP No. 07 pengklasifikasian aset tetap berhubungan dengan Standar Operasional Prosedur Dinas Tenaga Kerja dan Transmigrasi Provinsi Sulawesi Utara yaitu pada poin 3 (tiga) melaksanakan pengadaan barang sesuai dengan dokumen pengadaan, poin 4 (empat) melaksanakan verivikasi terhadap barang yang telah diadakan, dan poin 7 (tujuh) mengadakan penyaluran barang ke unit kerja yang membutuhkan sesuai perencanaan. Dalam hal ini aset tetap diklasifikasikan sesuai dengan sifat dan fungsi aktifitas entitas.

4. Dalam PSAP No. 07 pengungkapan aset tetap berhubungan dengan Standar Operasional Prosedur Dinas Tenaga Kerja dan Transmigrasi Provinsi Sulawesi Utara yaitu pada poin 8 (delapan) melakukan pengawasan terhadap aset tetap, poin 9 (sembilan) pembuatan laporan pertanggungjawaban sesuai dengan klasifikasi inventaris barang, poin 10 (sepuluh) pemeriksaan laporan pertanggungjawaban pengadaan aset tetap dan poin 11 (sebelas) pemeliharaan aset tetap Dinas Tenaga Kerja dan Transmigrasi Provinsi Sulawesi Utara. Dalam hal ini pengungkapan laporan aset tetap pada Dinas Tenaga Kerja dan Transmigrasi Provinsi Sulawesi Utara dinyatakan dalam neraca yang terpisah atau terperinci sesuai dengan pengklasifikasian. 


\section{Kesimpulan}

\section{PENUTUP}

Berdasarkan hasil penelitian dan pembahasan tentang evaluasi pengendalian akuntansi aset tetap berdasarkan Peraturan Pemerintah No. 71 Tahun 2010 pada Dinas Tenaga Kerja dan Transmigrasi Provinsi Sulawesi Utara, maka dapat ditarik kesimpulan sebagai berikut :

1. Pengendalian akuntansi aset tetap Dinas Tenaga Kerja dan Transmigrasi Provinsi Sulawesi Utara khususnya untuk aspek pengakuan aset tetap telah sesuai dengan Peraturan Pemerintah No. 71 tahun 2010 tentang akuntansi aset tetap.

2. Pengendalian akuntansi aset tetap Dinas Tenaga Kerja dan Transmigrasi Provinsi Sulawesi Utara khususnya untuk aspek pengukuran aset tetap telah sesuai dengan Peraturan Pemerintah No. 71 tahun 2010 tentang akuntansi aset tetap.

3. Pengendalian akuntansi aset tetap Dinas Tenaga Kerja dan Transmigrasi Provinsi Sulawesi Utara khususnya untuk aspek pengklasifikasian aset tetap telah sesuai dengan Peraturan Pemerintah No. 71 tahun 2010 tentang akuntansi aset tetap.

4. Pengendalian akuntansi aset tetap Dinas Tenaga Kerja dan Transmigrasi Provinsi Sulawesi Utara khususnya untuk aspek pengungkapan aset tetap telah sesuai dengan Peraturan Pemerintah No. 71 tahun 2010 tentang akuntansi aset tetap.

\section{Saran}

Berdasarkan pada penelitian yang dilakukan dan hasil kesimpulan yang telah diperoleh, maka saran yang diajukan yaitu dalam pengendalian akuntansi aset tetap untuk dapat mempertahankan prosedur pengendalian aset tetap sesuai aturan yang berlaku.

\section{DAFTAR PUSTAKA}

Kieso, D. E., Weygandt, J. J., \& Warfield, T. D (2011). Intermediate Accounting Volume 1 IFRS Edition. United States of America : Wiley.

La Midjan dan Azhar Susanto. 2011. Sistem Informasi Akuntansi. Edisi Kedelapan. Linggajaya, Bandung. Mahmudi, 2010. Analisis Laporan Keuangan Pemerintah Daerah. Edisi Kedua. UPP STIM YKPN, Yogyakarta.

Weygandt, Kimmel, Kieso. Financial Accounting IFRS Edition. 2011. Jhon Willey \& Sons Inc, USA.

Wild, John J., Ken W Shaw dan Barbara Chiappetta. 2014. Financial Acoounting Information For Decisions Is A Asian Adaption Of Fundamental Accounting 20th Edition. Mc Graw Hill Aducation (Asia), Singapore.

Hariadi, Pramono, Yanuar E. Restiyanto dan I.R Bawono. 2010. Pengelolaan Keuangan Daerah. Penerbit Alfabeta Bandung.

Yusuf, M. 2011. 8 Langkah Pengelolaan Aset Daerah Menuju Pengelolaan Keuangan Daerah Tebaik, Cetakan Kedua. Salemba Empat, Jakarta 